\title{
PROCEDEU DE ÎNMULŢIRE ÎN MASĂ A ENTOMOFAGULUI Trichogramma evanescens $\mathbf{W}$.
}

\author{
Gorban V., Gavriliţa Lidia, Voineac V., Nastas T. \\ Institutul de Genetică, Fiziologie şi Protecţie a Plantelor, Chișinău, Republica Moldova \\ e-mail:vgorban.alimeco@yahoo.com
}

În prezent, multe țări ale lumii sunt preocupate de căutarea metodelor nonchimice și a mijloacelor de protecție a plantelor împotriva dăunătorilor și bolilor. În multe cazuri, utilizarea insectelor entomofage utile pentru combaterea insectelor dăunătoare culturilor de câmp, livezilor și pădurilor este destul de eficientă. Pentru aceasta este important obținerea unui material biologic de calitate înaltă, care va servi în procesul tehnologic ca substrat nutritiv pentru reproducerea eficientă în masă a entomofagului Trichogramma evanescens W.

În procesul elaborării tehnologiei de reproducere în masă a trichogramei, s-a constatat că utilizarea ouălor gazdă sterilizate, în acest scop, duce la majorarea eficientei procesului cu 10-15\%.

Este cunoscut modul de sterilizare prin utilizarea mutagenilor fizici (radiaţie gama, izotopi de cobalt, cesiu şi alte elemente) sau chimici (anumiţi agenţi de alchilare, în special derivații etilendiamina şi anumiţi antimetaboliţ̧i), care induc mutaţii letale dominante pupelor sau adulţilor insectelor dăunătoare. Unul din aceste moduri este procedeul de producere în masã a Trichogramma evanescens W pe ouă de molia cerealelor (Sitotroga Cerealella Oliv) iradiate în prealabil cu raze gama.

Dezavantajul procedeelor cu utilizarea mutagenilor enumăraţi constă în faptul, că ei au o toxicitate ridicată, uneori şi o acţiune cancerogenă şi nu pot fi aplicate pe larg atât timp cât nu vor avea un efect selectiv şi relativ sigur pentru personalul de lucru.

$\mathrm{Cu}$ scopul majorârii eficacităţi procesului de înmulţire în masă a entomofagului Trichogramma s-a propus utilizarea razelor infraroşii cu efectul de sterilizare a ouălor de insectegazdă (molia cerealelor Sitotroga Cerealella Oliv) care sunt folosite în calitate de substrat nutritiv pentru reproducerea entomofagului dat (Brevet de invenție MD1003Z 2016.09.27).

Procedeul de sterilizare a ouălor de insecte are loc în rezultatul iradierii ouălor gazdei cu raze infraroşii cu lungime de undă 750-1000 nm emanate de sursa cu o putere de 250Wt situată deasupra vasului la înălţimea de $250-300 \mathrm{~mm}$, timp de $4-5$ min. Razele infraroşii au proprietăţi fizice de a pătrunde sub corionul ouălor şi de a fi absorbite de compusul lor lichid, acţionând termic asupra embrionului, în rezultat încetează dezvoltarea de mai departe a larvelor în acelaşi timp ouăle sterilizate îşi păstrează calităţile nutritive necesare pentru creşterea în masă a entomofagului Trichogramma sau păstrate un timp îndelungat în condiţ̧i optimale şi utilizate după necesitate.

Rezultatul tehnic obţinut se datorează faptului, că procedeul propus asigură sterilizarea ouălor insectelor-gazdă (moliei cerealelor - Sitotroga Cerealella Oliv) cu un randament de 80-85\%, păstrând calitățile nutritive ale ouălor utilizate în calitate de gazdă alternativă la creșterea în masă a entomofagului Trichogramma. Procedeul propus de sterilizare, spre deosebire de procedeele cunoscute este uşor de utilizat, nu necesită operator special, nu aç̧ionează agresiv asupra materialului biologic ori a personalului de lucru, prin urmare el se referă la tehnologiile ecologic inofensive, în acelaşi timp necesită un consum redus de energie. 